\title{
Relationship Marketing and Customer Retention in the Ghanaian Banking Industry
}

\author{
Nicholas Oblitei Commey ${ }^{1 *} \quad$ Kwame Adom ${ }^{2}$ \\ 1.School of Business and Leadership, Heritage Christian University College, P. O. Box AN 16798, Accra - \\ North, Ghana \\ 2.University of Ghana Business School, University of Ghana, P.O. Box LG 25, Legon - Accra
}

\begin{abstract}
The Ghanaian banking industry has experienced a heightened level of competition in recent times due to the recent banking sector clean-up by the Bank of Ghana (BOG) which has resulted in a number of mergers, acquisitions and bank closures. As a result of this development, banks in Ghana have adopted relationship marketing (RM) as a strategy to attract new customers and for customer retention purposes. This research seeks to investigate the impact of relationship marketing (RM) on customer retention in the Ghanaian banking industry. It also examined the impact of relationship marketing (RM) on customer satisfaction as well as the impact of customer satisfaction on customer retention in the Ghanaian banking industry. A survey of customers from twenty banks was conducted using a questionnaire. The results revealed that relationship marketing account for a significant variation in the extent of customer retention in the Ghanaian banking industry. The study further revealed that customer satisfaction also accounts for the level of customer retention in the Ghanaian banking sector. The study also discovered that banks in Ghana are able to retain their customers even without employing non-financial benefits, which is considered as very essential in the implementation of RM practices. This indicates that banks in Ghana which employ non-financial benefits in addition to financial benefits could have a competitive urge over other competitors in the Ghanaian banking industry. As a consequence, there is a call on Ghanaian banks to implement effective relationship marketing strategies in order to ensure the retention of their customers. Furthermore, banks should employ strategies that will ensure that their customers are satisfied in order to guarantee higher level of retention of their customers
\end{abstract}

Keywords: Relationship Marketing, Customer Retention, Banking, Ghana.

DOI: $10.7176 / \mathrm{EJBM} / 12-29-01$

Publication date:October $31^{\text {st }} 2020$

\section{Introduction}

The Ghanaian banking industry has experienced a heightened level of competition in recent times. This is due to the fact that universal banks are also competing with non-banks and other financial institutions (Chacha, 2015), mainly because product developments are easy to duplicate and banks provide nearly identical services (Msoka \& Msoka, 2014). This is also partly due to the recent banking sector clean-up by the Bank of Ghana (BOG) which started in 2017 and has resulted in a number of mergers, acquisitions and bank closures. The action by the BOG resulted in the revocation of licenses of 9 universal banks, 347 microfinance companies, 39 micro credit companies, 15 savings and loans companies, eight (8) finance house companies and two (2) non-bank financial institutions (Affum, 2020). Although this move by BOG is to re-establish confidence and sanity in the banking and specialized deposit-taking sector in Ghana, it appears it partly had a negative impact on the banking sector as it resulted in a slow growth rate among commercial banks amid slow deposits (Modern Ghana, 2020). In line with this development, Affum (2020) averred that the exercise has resulted in generally low deposits, whereas withdrawals have been very high, and these were due to fear and panic of losing funds or investments and loss of confidence among the banking population. Additionally, banks are unable to retain their customers as customers switch from one bank to another resulting in a decline in the number of repeat businesses (Chacha, 2015). This implies that banks in Ghana need to adopt innovative strategies and measures in order to be able to attract new customers and to retain existing customers. One of such strategies that banks have adopted to achieve this objective is relationship marketing (RM).

Relationship marketing (RM) as a concept has gained a wide purchase across the globe and it is practiced widely within the banking industry. Before the emergence of RM, the concept of marketing was mostly concentrated on transactional marketing (Sheth \& Parvatiyar, 2000). This was because most marketers in those days practiced mass marketing. As a result of this, firms suffered from the leaking bucket effect (Christopher, Payne, \& Ballantyne, 1991). This affected the profitability of most firms since they always have to incur huge expenditures on promotional activities to attract new customers to patronize their products and services. This development, coupled with other factors such as increasing competition, rapid technological advances, greater adoption of information technologies in business operations, the impact of globalization, the adoption of total quality programs by firms and the growth of the service sectors gave rise to the development of the relational aspects of marketing (Sheth \& Parvatiyar, 2000). 
These developments led to a great saturation in many markets and as a result consumers were faced with a lot of choices with regards to which products and services to patronize, hence consumers became more demanding and less persuaded by the promotional messages of sellers. It also affected many businesses as it led to a decline in their market share and subsequently in the profitability of business organizations (Filip \& Anghel, 2006). These compelled businesses to realize that the methods, techniques and instruments of traditional marketing were not as effective as before and as a result companies were not able to plan their activities effectively and to predict their future market positioning (Filip \& Anghel, 2006). In view of these developments marketing has now changed from transactional to relational marketing (Christopher et al., 1991).

RM has attracted a lot of attention and as a result has gained prominence among scholars and practitioners. A number of reasons can be attributed for the prominence of RM across many economic landscapes. Rindova and Fombrum (1999) mentioned that RM can contribute to help firms establish and maintain a competitive urge over its competitors by ensuring the retention of their customers. Dawkins and Reichheld (1990) also opined that a 5 per cent increase in customer retention leads to an increase in customer net present value of between 25 and 95 per cent across business environments. Other important factors mentioned for the need to adopt RM include the need for customer retention (Reichheld \& Sasser, 1990) and its impact on profitability, the failure of the mass media to assist decision-making process by customers (Copulsky \& Wolf, 1990) among others. As a result of these and other factors various studies have been conducted on RM in various parts of the world and focused on various dimensions and practices, and these have contributed a lot to the development of many firms in both the service and industrial sectors.

The review of the extant literature indicates that most studies confirmed a positive relationship between RM and customer satisfaction as well as loyalty (Aldaihani \& Ali, 2019; Djajanto, Afiatin, \& Haris, 2019; Kyei \& Narteh, 2016; Aka, Kehinde, \& Ogunnaike, 2016; Husnain, \& Akhtar, 2016; Narteh, 2009; Anabila, Narteh, \& Tweneboah-Koduah, 2012; Rootman, Tait, \& Sharp, 2011; Olotu, Maclayton \& Opara, 2010; Narteh, 2009; Ndubisi, 2006). In view of these findings, a number of banking institutions have adopted relationship marketing strategies in order to gain a competitive urge in the face of the intensity of competition in the Ghanaian banking sector. Banks have also adopted RM as a strategy to enhance their profitability and survival. Despite the shifted attention on RM, most of the studies and efforts are concentrated on the impact of RM on satisfaction and loyalty, without giving much attention to the impact of RM on customer retention which is considered as an outcome of customer loyalty, hence the decision to research into this area in order to provide added knowledge to the literature. This study also adds to the literature by investigating the impact of customer satisfaction on customer retention in the Ghanaian banking industry. The findings will provide a more reliable and scientific measure for evaluating the satisfaction and retention rates of organizations. This will inform practitioners as to the effectiveness of the relationship marketing strategies adopted by their firms and make a decision as to whether to maintain or adopt new strategies.

The study is structured as followed: Literature will be reviewed on RM, the antecedents of RM and on the outcomes of RM. This will be followed by a discussion of the methodology employed, data analysis and finally the findings of the study.

\section{Theoretical Foundation of the Study}

The theoretical foundation for this study is the commitment - trust theory developed by Morgan and Hunt. This theory indicates that relationship commitment and trust are essential requirements of a successful relationship (Morgan \& Hunt, 1994). The theory indicates that there is a positive relationship between antecedents such as relationship termination cost, relationship benefits, shared values and relationship commitment as mediating constructs. It also indicated that there is a positive relationship between antecedents such as shared value and communication and trust as a mediating construct. The commitment - trust theory have been employed by scholars in numerous studies in areas such as retailing, banking and finance, as well as tourism and hospitality (Mukherjee \& Nath, 2007; Nusair, Bilgihan \& Okumus, 2013; Gan, Sim, Tan, \& Tna, 2007). Although these variables have been used across diverse industries, all these studies confirm commitment and trust as key variables that are relevant to any successful relational exchange involving suppliers, customers and employees (Morgan \& Hunt, 1994). What this theory suggests is that relationships between banks and their customers would not be successful without the presence of commitment and trust. This implies that when banks implement measures to engage in a relationship with their customers, they must ensure the presence of commitment and trust since the relationship will not be successful without those two dimensions. Based on these assertion, this study theorises that commitment and trust are key practices without which a bank will not be able to successfully attract and retain its existing customers.

\section{Literature Review}

3.1 Relationship Marketing (RM)

Berry (1983) defined RM as a strategy to attract, maintain and enhance customer relationships. Grönroos (1994) 
adapted the definition by Berry (1983) when he defined RM as a strategy to attract, maintain and enhance relationships with customers and other parties at a profit, with the aim of ensuring that the objectives of the firm and all parties involved are achieved. RM was also defined by Walsh, Gilmore, and Carson (2004) as all activities adopted by banks in order to attract, interact with, and retain more profitable clients. These explanations by Grönroos (1994) and Walsh et al. (2004) indicate that firms adopt RM with the main purpose of maintaining the relationship with customers and making profit. This study therefore adopts the definition by (Grönroos, 1994). Although RM is mostly concerned with maintaining relationships, there are times when relationships with some customers need to be terminated. This is emphasized in the definition by Grönroos (2001) who postulated that the main purpose of RM is to identify, establish, maintain, enhance and when necessary terminate relationships with customers and other parties so that the economic and other benefits of the relationship will be achieved through mutual exchange and fulfillment of promises.

\subsection{Relationship Marketing (RM) Practices}

A number of practices have been considered very essential in the implementation of RM. These include trust (Morgan \& Hunt, 1994; Ndubisi, 2004), competence (Anderson \&Weitz, 1989; Wah, 2004), conflict handling (Dwyer, Schurr, \& Oh, 1987; Ndubisi \& Wah, 2005), communication (Ndubisi \& Wah, 2005; Morgan \& Hunt, 1994; Crosby, Evans, \& Cowless, 1990), commitment (Grossman, 1998; Wah \& Ndubisi, 2004), and bonding (Taleghani, Gilaninia, \& Mousavian, 2011).

Anderleep (1996) explained trust as existing in a relationship when one party in a relationship feels secure based on the belief that the outcome of the relationship with the other party will be positive. In line with the explanation by Anderleep (1996), Morgan and Hunt (1994) conceptualized trust as existing in a relationship when one party has confidence in the reliability and integrity of the other party. Trust is considered as an important ingredient in relationships between a firm and customers and ultimately in the development of loyalty (Taleghani et al., 2011). What this means is that loyalty will be absent in a relationship where trust does not exist (Morgan \& Hunt, 1994). Generally, it appears that the greater the level of trust between parties in a relationship, the higher the probability that the existence of the relationship will be long lasting (Martin \& Sohi, 1993).

Competence is defined by Anderson and Weitz (1989) as the buyer's perception of the supplier's technological and commercial competence. They operationalized competence in four ways: the supplier's understanding about the market of the buyer, the capability to give good advice on the operating business, the ability to help the buyer plan purchases, and the ability to provide effective sales promotion materials. Narteh (2009) mentioned that within banking, competence could mean deploying knowledgeable employees with the capability of providing accurate and first class banking services. This implies that it would be difficult for institutions to attract and retain customers if they do not possess accurate knowledge about their products and operations.

Conflict handling is defined as a firm's ability to avoid potential conflicts and find solutions to conflicts before they degenerate into problems and discuss solutions openly when problems do occur (Dwyer, Schurr, \& Oh, 1987). Narteh (2009) posits that banks skills in handling potential conflicts have a great impact on customer satisfaction since it serves as an assurance that the bank is interested in their welfare. "Frequency and bidirectional communications has the strongest effects on interpersonal conflicts and communication should be meaningful, supportive and appropriate to be more effective" (Meunier-FitzHugh \& Piercy, 2010). This implies that for firms to be able to prevent conflicts from degenerating into serious conflicts, they must ensure open and effective communications with their customers.

Communication is a very essential element of relationship marketing. It is explained as keeping in touch with customers, providing timely and trustworthy information, and communicating proactively when delivery problems occur (Ndubisi, 2007). Ndubisi and Wah (2005) postulates that communication in relationship marketing means providing information that can be trusted, providing information when delivery problems occur, providing information on quality problems and fulfilling promises. Firms need to play a very important role for communications to be effective. Taleghani et al. (2011) indicated that providers must build awareness, develop consumer preference by promoting value, performance and other features, convince interested buyers, and encourage them to make the purchase decision and as well inform dissatisfied customers of what the organization is doing to rectify the causes of dissatisfaction.

Commitment is another important dimension of RM. Moorman, Zaltman, and Deshpande (1992) defined commitment as a lasting desire to preserve a valued relationship. Morgan and Hunt (1994) also view commitment as a partner's belief that an exchange relationship is important and demand maximum effort to maintain it. Mowday, Porter, and Steers (1982) opined that commitment is higher among customers who believe they receive more value from a relationship. The implication of this is that firms should ensure that customers get more value from the relationship in order to get them to be committed. Sherma, Krishnan, and Grewal (2001) contend that to ensure commitment of parties in a relationship, the parties must share complimentary values and goals about the expectations and obligations involved in the relationship. According to Anderson and Weitz (1992), commitment 
to a relationship will result in a longing to develop a firm relationship and a willingness to make short-term sacrifices to maintain the relationship.

Bonding is also considered an essential dimension of relationship marketing. It is defined as "the psychological, emotional, economic, or physical attachments in a relationship that are fostered by association and interaction and serve to bind parties together under relational exchange" (Smith, 1998). Anderson and Weitz (1989) defined bonding as the buyer's perception of the supplier's technological and commercial competence. Calaghan, McPhail, and Yau (1995) also posit that bonding refers to the development of an emotional relationship between two parties acting in a unified manner toward a desired goal. Hinde (1997) averred that bonding creates trust and form close relationships between parties in a relationship. This implies that if firms ensure that the bond with their customers is strong, it could also lead to ensuring that their customers trust the firm and their operations.

\subsection{Customer Satisfaction}

Customer satisfaction is very essential to every organization since satisfied customers are always more credible to be loyal to a firm (Lee \& Lin, 2005) and tend to be less price sensitive, buy more of the firm's products, are hardly influenced by competitors and are known to stay longer in a relationship with the provider (Zineldin, 2000). Kotler and Keller (2006) explained satisfaction as a person's feeling of pleasure or disappointment which results from comparing the performance of the product to his or her expectation. This is in line with the explanation by Oliver (1999) that customer satisfaction is consumers' post purchase evaluation and affective response to the overall product or service experience. Customer satisfaction is said to enhance customer retention (Ericksson \& Lofmarck, 2000). This clearly indicates that customer satisfaction is an antecedent or precursor to customer retention (Athanassopoulos, 2000).

\subsection{Customer Retention}

Grönroos (1995) posits that the main aim of relationship marketing is to acquire and retain customers. This explains the importance of customer retention in relationship marketing. Customer retention refers to strategies adopted by organizations with the main aim of reducing customer defections. Grönroos (1991) posits that customer retention is the primary goal of firms that adopt relationship marketing. Gerpot, Rams and Schindler (2001) posits that customer retention focuses on maintaining the business relationship established between an organization and a customer. The importance of customer retention is demonstrated in a number of studies. Gupta, Lehmann, and Stuart (2004) posited that a 1 per cent increase in customer retention had an impact of almost five times more on a firm's value than a 1 per cent change in discount rate or cost of capital. Lindgreen, Davis, Brodie, and BuchananOliver (2000) also indicated that customer acquisition can be up to ten times more expensive than customer retention and also posits that the resources invested in getting a new customer to the same level of profitability as a lost customer is up to 16 times more.

\section{Conceptual Model and Hypothesis}

Based on the review of the extant literature, the conceptual model below was developed leading to the formulation of the hypothesis.

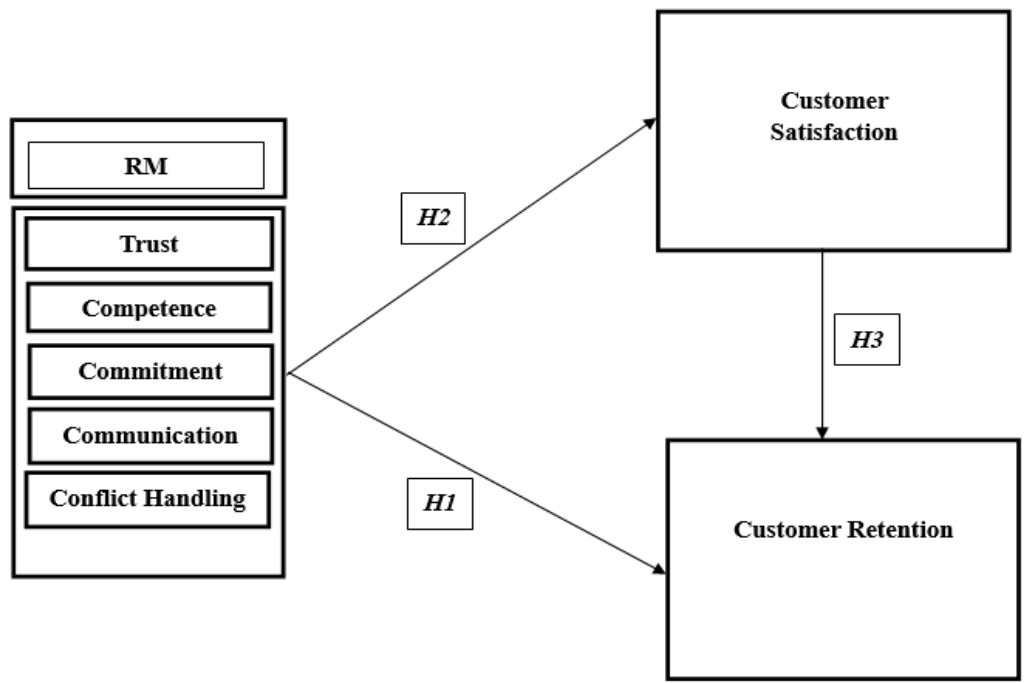

Figure 1: Conceptual Model

H1: There is a significant relationship between relationship marketing and customer retention.

H2: There is a significant relationship between relationship marketing and customer satisfaction.

H3: There is a significant relationship between customer satisfaction and customer retention. 


\section{Methodology}

The study adopted a quantitative approach using self-administered questionnaires to collect information from the respondents. One set of questionnaire was developed for the selected banks involved in the study. The questionnaire was divided into two parts, thus Section A and Section B. Section A is made up of questions concerning the background of the respondents. Section B is subdivided into eight parts. These parts contain questions relating to the RM dimensions, customer satisfaction, and customer retention. The questionnaires were distributed among customers of the various banks selected for the study.

In all, 357 out of the 400 questionnaires distributed representing 89.25 per cent was analysed. The data were analysed mainly using Statistical Package for Social Sciences (SPSS). The measures used for each of the independent variables were first rotated using Varimax rotation with Kaiser normalization. This was done to delete measures which loaded below 0.50 (Hair et al., 1998). However, all the measures loaded above 0.50 and they were loaded onto six factors. There was no cross loading on any factor.

After the measures were rotated, the Kaiser-Meyer-Olkin (KMO) Measure of Sampling Adequacy and Bartlett's Test of Sphericity (BTS) were used to access whether there were significant correlations among the variables to warrant for factor analysis and to ascertain the suitability of factor analysis. The variables were then tested for normality by employing skewness and kurtosis measures. After this the reliability of the various measures were ascertained by checking the Cronbach Alpha values for each of the measures. All the Cronbach Alpha values obtained were above 0.70 , as specified by (Nunnally, 1978). Regression analysis was then conducted to test the impact of RM on customer retention and also the impact of RM on customer satisfaction. Regression analysis was also used to test the impact of customer satisfaction on customer retention.

\section{Data Analysis, Interpretation and Discussion}

\subsection{Descriptive Statistics}

Mean statistics help us to examine the central tendency of the various constructs adopted for the study. Table 1 indicates that the highest mean is 4.0504. This is in relation to whether customers have been loyal to their banks. This shows that most of the respondents, in this case the customers of the bank agreed that they have been loyal to their respective banks. This also indicates that the RM strategies employed by the various banks have been very effective. This has ensured that the customers remain loyal to their banks.

The least mean score is 1.9552 . This is in relation to whether the banks send gifts to their customers on special occasions. The score is closer to 2 on the Likert scale of 1 to 5 which represents disagree. This indicates that most of the customers disagree with the fact that their banks send them gifts on special occasions. This means that Ghanaian banks do not usually employ non-financial benefits as a strategy to retain their customers. It also means that most customers on their part do not view non-financial gifts as reason for engaging in relationships with their bankers. This is illustrated in table 1.

Table 1: Descriptive Statistics of Variables

\begin{tabular}{|c|c|c|c|c|c|}
\hline & $\mathbf{N}$ & Minimum & Maximum & Mean & $\begin{array}{c}\text { Std. } \\
\text { Deviation }\end{array}$ \\
\hline $\begin{array}{l}\text { My bank is very concerned with the security of } \\
\text { my transactions }\end{array}$ & 357 & 1 & 5 & 4.042 & 0.94567 \\
\hline My bank's words and promises are reliable & 357 & 1 & 5 & 3.6611 & 0.92102 \\
\hline $\begin{array}{l}\text { My bank is consistent in providing quality } \\
\text { service }\end{array}$ & 357 & 1 & 5 & 3.6611 & 0.98584 \\
\hline $\begin{array}{l}\text { Employees of my bank show respect to } \\
\text { customers }\end{array}$ & 357 & 1 & 5 & 3.8123 & 0.93079 \\
\hline My bank fulfills its obligations to customers & 357 & 1 & 5 & 3.7171 & 0.89069 \\
\hline $\begin{array}{l}\text { I have confidence in my bank's service delivery } \\
\text { processes }\end{array}$ & 357 & 1 & 5 & 3.8459 & 0.894 \\
\hline My bank has knowledge about banking services & 357 & 1 & 5 & 4.2241 & 0.79336 \\
\hline $\begin{array}{l}\text { My bank has knowledge about the market trend } \\
\text { My bank provides me with advice on how I }\end{array}$ & 357 & 1 & 5 & 4.0112 & 0.8578 \\
\hline should invest my money & 357 & 1 & 5 & 2.9132 & 1.20894 \\
\hline My bank helps me to plan my investments & 357 & 1 & 5 & 2.7283 & 1.10495 \\
\hline My bank makes adjustments to suit my needs & 357 & 1 & 5 & 2.8319 & 1.15622 \\
\hline My bank makes adjustments to suit my needs & 357 & 1 & 5 & 2.8263 & 1.02117 \\
\hline $\begin{array}{l}\text { My bank offers personalized services to meet } \\
\text { customer needs. }\end{array}$ & 357 & 1 & 5 & 3.2773 & 0.98521 \\
\hline
\end{tabular}


Std.

\begin{tabular}{|c|c|c|c|c|c|}
\hline & $\mathbf{N}$ & Minimum & Maximum & Mean & Deviation \\
\hline \multirow{3}{*}{$\begin{array}{l}\text { My bank is flexible in serving my needs. } \\
\text { I am resolute about future intent to do business } \\
\text { with my bank }\end{array}$} & 357 & 1 & 5 & 3.3305 & 0.96715 \\
\hline & & & & & \\
\hline & 357 & 1 & 5 & 3.5714 & 1.02419 \\
\hline \multirow{2}{*}{$\begin{array}{l}\text { My bank provides timely and trustworthy } \\
\text { information. }\end{array}$} & & & & & \\
\hline & 357 & 1 & 5 & 3.6415 & 1.01962 \\
\hline $\begin{array}{l}\text { My bank provides information when there is } \\
\text { new banking service }\end{array}$ & 357 & 1 & 5 & 3.7591 & 1.0018 \\
\hline $\begin{array}{l}\text { Information provided by the bank is always } \\
\text { accurate. }\end{array}$ & 357 & 1 & 5 & 3.6835 & 0.92292 \\
\hline $\begin{array}{l}\text { My bank encourages regular contact and open } \\
\text { dialogue on frequent basis }\end{array}$ & 357 & 1 & 5 & 3.1429 & 1.15354 \\
\hline \multirow{2}{*}{$\begin{array}{l}\text { My bank tries to avoid potential conflict } \\
\text { My bank tries to solve manifest conflicts before } \\
\text { they create problems }\end{array}$} & 357 & 1 & 5 & 3.6471 & 0.92337 \\
\hline & 357 & 1 & 5 & 3.5798 & 0.91948 \\
\hline $\begin{array}{l}\text { My bank has the ability to openly discuss } \\
\text { solution when problems arise. }\end{array}$ & 357 & 1 & 5 & 3.4958 & 0.97041 \\
\hline \multirow{2}{*}{$\begin{array}{l}\text { My bank is responsive to my complaints } \\
\text { My bank shows a sincere interest in solving } \\
\text { customer problem }\end{array}$} & 357 & 1 & 5 & 3.6359 & 0.97534 \\
\hline & 357 & 1 & 5 & 3.6723 & 0.98108 \\
\hline We keep in touch constantly & 357 & 1 & 5 & 3.0756 & 1.0718 \\
\hline \multirow{2}{*}{$\begin{array}{l}\text { We work in close collaboration } \\
\text { We both try very hard to establish a long-term } \\
\text { relationship }\end{array}$} & 357 & 1 & 5 & 3.0084 & 0.94062 \\
\hline & 357 & 1 & 5 & 3.1737 & 1.04563 \\
\hline We rely on each other & 357 & 1 & 5 & 3.0364 & 1.05272 \\
\hline \multirow{2}{*}{$\begin{array}{l}\text { My bank send me gifts on special occasions } \\
\text { My bank offers me special pricing on my } \\
\text { transactions }\end{array}$} & 357 & 1 & 5 & 1.9552 & 1.16513 \\
\hline & 357 & 1 & 5 & 2.0812 & 1.11759 \\
\hline \multirow{2}{*}{$\begin{array}{l}\text { I am very pleased with my bank's services } \\
\text { My experiences with my bank have always been } \\
\text { good }\end{array}$} & 357 & 1 & 5 & 3.3866 & 1.05556 \\
\hline & 357 & 1 & 5 & 3.4118 & 1.02287 \\
\hline \multirow{2}{*}{$\begin{array}{l}\text { Overall, I am very satisfied with my bank } \\
\text { If I had to do it all over again, I would still } \\
\text { choose to use this bank }\end{array}$} & 357 & 1 & 5 & 3.4874 & 1.05627 \\
\hline & 357 & 1 & 5 & 3.4118 & 1.22069 \\
\hline \multirow{2}{*}{$\begin{array}{l}\text { I am willing to recommend my bank to others } \\
\text { I will patronize more of my banks products and } \\
\text { services }\end{array}$} & 357 & 1 & 5 & 3.5098 & 1.18418 \\
\hline & 357 & 1 & 5 & 3.5042 & 1.14072 \\
\hline I have been loyal to my bank & 357 & 1 & 5 & 4.0504 & 0.95854 \\
\hline I will continue to do business with my bank & 357 & 1 & 5 & 3.7423 & 1.1045 \\
\hline
\end{tabular}

5.2 Normality of Variables

One way of assessing the normality of distribution is by examining the skewness and kurtosis values of the data. Skewness is the measure of the symmetry of a distribution. The comparison is made to a normal distribution and is between the range of -1 to +1 (Hair, Black, Babin, Anderson, \& Tathan, 2006). The values obtained, as indicated in table 2 falls within the range. This shows that all the variables are normally distributed and suitable for the study. Kurtosis measures the flatness of a distribution when compared with a normal distribution. This should be between the ranges of -3 and +3 . The values obtained, as indicated in table 2 falls within the range. This shows that all the variables are normally distributed. 
Table 2: Normality of Variables

\begin{tabular}{lcccc}
\hline & Mean & Skewness & Kurtosis & No. of Items \\
\hline Trust & 3.790 & -0.548 & 0.257 & 6 \\
Competence & 3.342 & -0.798 & 0.790 & 5 \\
Commitment & 3.251 & -0.310 & -0.191 & 4 \\
Communication & 3.557 & -0.254 & -0.286 & 5 \\
Conflict Handling & 3.606 & -0.290 & 0.146 & 6 \\
Bonding & 2.722 & 0.825 & -0.289 & 4 \\
Customer Satisfaction & 3.424 & -0.390 & -0.490 & 4 \\
Customer Retention & 3.702 & -0.526 & -0.175 & \\
\hline \hline
\end{tabular}

5.3 Varimax Rotated Principal Component Loadings

The measures adopted for each of the independent variables were rotated using Varimax rotation with Kaiser Normalization. This was done to delete measures which loaded below 0.50 (Hair et al., 1998). As table 3 indicates, all the measures loaded above 0.50 and they were loaded onto six factors. There was no cross loading on any factor. Six factors loaded onto trust, five loaded onto competence, four loaded onto commitment, four loaded onto communication, five onto conflict handling and six onto bonding.

Table 3: Varimax Rotated Principal Component Loadings

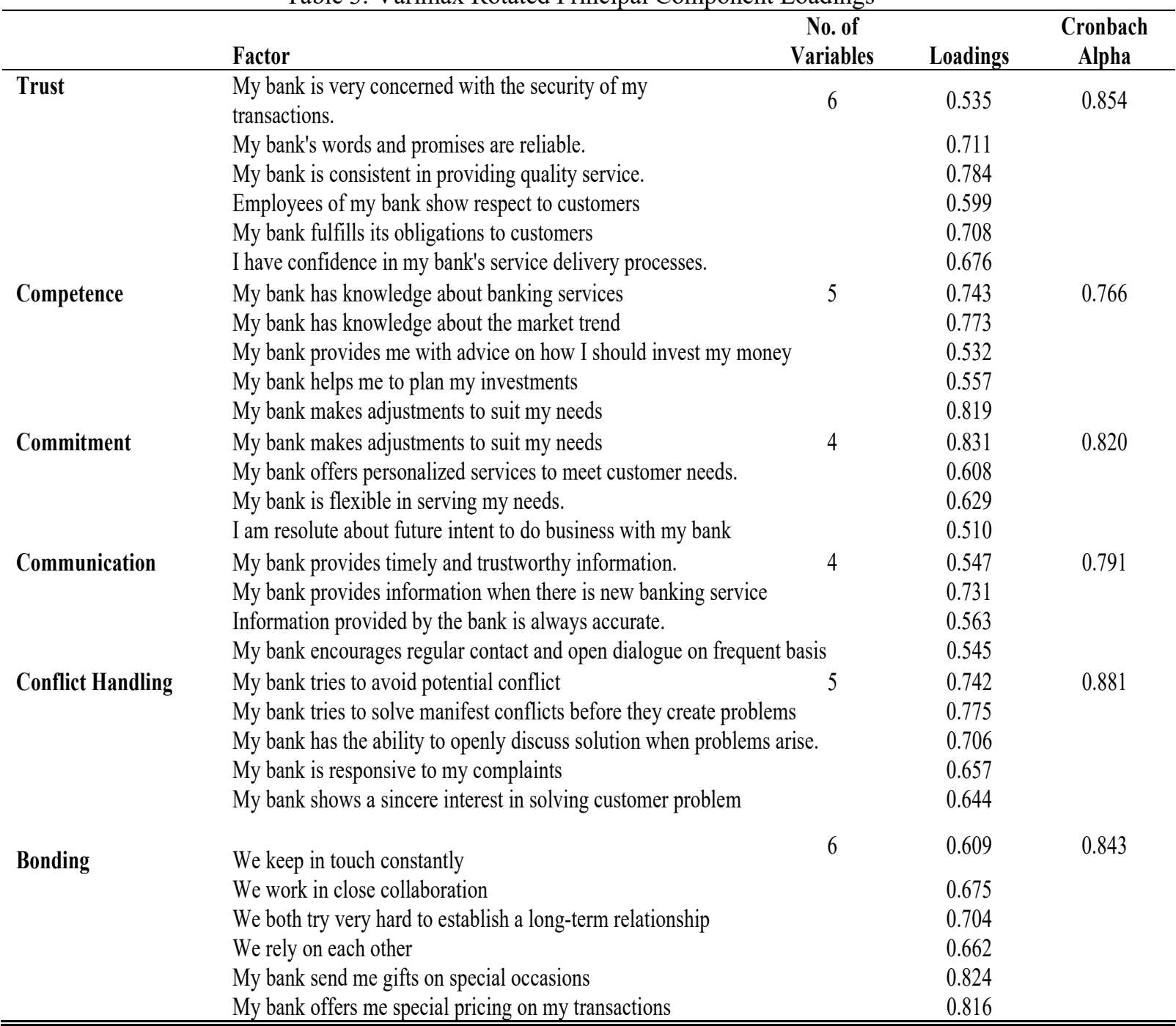

5.4 The Dependent Variables (Loadings)

The loadings and Cronbach Alpha of all the measures under the dependent variables were checked. All the measures loaded above 0.50. Again they all had Cronbach Alpha values of more than 0.70, as illustrated in table 4. This indicates that all the measures were reliable and would be suitable for the study. 
Table 4: Loadings of Dependent Variables

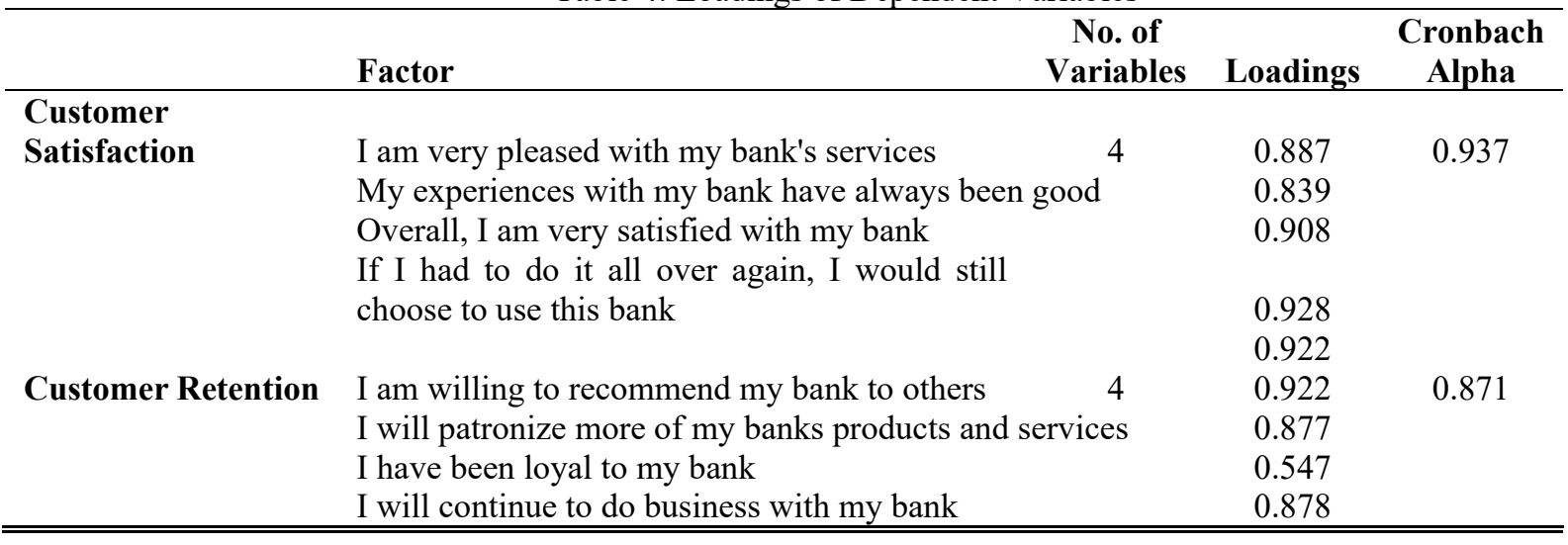

5.5 Factor Analysis and Scale Reliability

The Kaiser-Meyer-Olkin (KMO) Measure of Sampling Adequacy is a statistic tool that indicates the proportion of variance in the variables that might be caused by underlying factors and also examines whether there were significant correlations among the variables to warrant for factor analysis and to ascertain the suitability of factor analysis. High values (close to 1.0) generally indicate that a factor analysis may be useful with the data used for the study. If the value is less than 0.50 , the results of the factor analysis probably would not be very useful. The value obtained as indicated in table 5 is 0.91 . This indicates that all the values are greater than 0.50 . This shows that the results of the factor analysis obtained using the data gathered will be very useful.

Bartlett's Test of Sphericity (BTS) also measures the usefulness of factor analysis for the data used to conduct the study and also examines whether there were significant correlations among the variables to warrant for factor analysis and to ascertain the suitability of factor analysis. Small values (less than 0.05 ) of the significance level indicate that a factor analysis may be useful with the data used for the study. A significant value of 0.000 was obtained for all the variables tested. This also indicates that factor analysis will be useful for the data used, as indicated in table 5 .

Cronbach's alpha is a measure of reliability. More specifically, alpha is a lower bound for the true reliability of a survey. This measurement of coefficient assesses the consistency of the entire scale (Cronbach, 1951). The generally agreed upon lower limit for the alpha value is 0.70 , although a lower limit of 0.60 is accepted (Nunnally, 1978). The lowest value obtained for this variables tested is 0.758 and the highest value obtained is 0.937 . This indicates that all the variables used in the study are reliable. It is indicated in table 5 .

Table 5: Factor Analysis and Scale Reliability

\begin{tabular}{lcccccc}
\hline & Factors & Total & \% of Variance & KMO & Bartlett's Test & $\begin{array}{c}\text { Cronbach } \\
\text { Alpha }\end{array}$ \\
\hline Trust & 1 & 3.484 & 58.06 & & $819.516^{* * *}$ & 0.854 \\
Competence & 1 & 2.588 & 51.752 & & $680.703 * * *$ & 0.758 \\
Commitment & 1 & 2.601 & 65.03 & & $479.536^{* * *}$ & 0.820 \\
Communication & 1 & 2.458 & 61.46 & 0.91 & $401.595 * * *$ & 0.791 \\
Conflict Handling & 1 & 3.387 & 67.738 & & $1022.975 * * *$ & 0.881 \\
Bonding & 1 & 3.398 & 56.639 & & $1050.435 * * *$ & 0.843 \\
Customer Satisfaction & 1 & 3.367 & 84.167 & & $1251.153 * * *$ & 0.937 \\
Customer Retention & 1 & 2.921 & 73.016 & & $896.028^{* * *}$ & 0.871 \\
\hline \hline
\end{tabular}

\subsection{Regression Analysis}

5.6.1 Impact of Relationship Marketing on Customer Retention

The ANOVA table (table 6 ) indicates a sig. value of 0.000 . The model summary also indicates an R square value of 0.607 . The sig. value of 0.000 indicates that statistically there is a strong significant relationship between relationship marketing and customer retention. The $\mathrm{R}$ square value of 0.607 indicates that 60.70 per cent of variations in customer retention is explained by RM. Therefore, it is concluded that $\boldsymbol{H} \boldsymbol{1}$ is accepted.

This finding is consistent with the findings of studies such as Hettiarachchy and Samarasinghe (2016), Prahalathan, Umakanth, \& Dineshkumar (2016), Chacha (2015), Rootman, Tait, \& Sharp (2011), Verhoef (2003), and Sin, Tse, Yau, Lee, \& Chow, R. (2002) which revealed that RM has a positive impact on retention among service firms. This implies that improvement in relationship marketing practices by banks will have a positive impact on retention of their customers. This means that customers regard the implementation of relationship 
marketing dimensions such as trust, competence, commitment, communication, conflict handling and bonding as very important determinants of their retention to their respective banks and also indicates that the retention of Ghanaian customers is dependent on the RM practices implemented by their respective banks.

Table 6: ANOVA (RM and Retention)

\begin{tabular}{lccccc}
\hline & Sum of Squares & df & Mean Square & F & Sig. \\
\hline Regression & 190.47 & 6 & 31.745 & 90.051 & $.000^{\mathrm{a}}$ \\
Residual & 123.384 & 350 & 0.353 & & \\
Total & 313.854 & 356 & & & \\
\hline \hline
\end{tabular}

$\mathbf{R}=\mathbf{0 . 7 7 9} \quad$ Adjusted R=0.600 $\quad$ R Square $=0.607$

Table 7 indicates the individual contribution of the various dimensions of RM to retention. It shows that trust, competence, commitment, communication, conflict handling and bonding jointly contribute to determine the extent of customer retention. The highest determinant though is trust. This is followed by conflict handling, communication, bonding, commitment, and competence respectively. Among the dimensions, trust, conflict handling, communication, bonding and commitment all have significant effects on customer retention as their $\mathrm{p}$ values are less than $0.05(\mathrm{p}<0.05)$ while competence contributes to determine customer retention to a very minimal degree as the $p$-value obtained for competence is greater than $0.05(\mathrm{p}>0.05)$. This is illustrated in table 7 .

Table 7: Regression (RM and Retention)

\begin{tabular}{lccccc}
\hline & Unstandardized Coefficients & $\begin{array}{c}\text { Standardized } \\
\text { Coefficients }\end{array}$ & t & Sig. \\
\hline & $\mathrm{B}$ & Std. Error & Beta & & \\
(Constant) & -0.317 & 0.181 & & -1.749 & 0.081 \\
Trust & 0.476 & 0.061 & 0.368 & 7.836 & 0.000 \\
Comptence & -0.047 & 0.063 & -0.037 & -0.737 & 0.462 \\
Commitment & 0.121 & 0.060 & 0.104 & 2.006 & 0.046 \\
Communication & 0.222 & 0.058 & 0.190 & 3.830 & 0.000 \\
Conflict Handling & 0.246 & 0.060 & 0.205 & 4.121 & 0.000 \\
Bonding & 0.118 & 0.055 & 0.100 & 2.155 & 0.032 \\
\hline \hline
\end{tabular}

The regression (prediction) equation on the above model can be presented as follows:

If Customer retention $=\mathrm{Y} 1$, Trust $=\mathrm{X} 1$, Competence $=\mathrm{X} 2$, Commitment $=\mathrm{X} 3$, Communication $=\mathrm{X} 4$, Conflict Handling $=\mathrm{X} 5$, Bonding $=\mathrm{X} 6$ and Error term $=\mathrm{E}$, then

$\mathrm{Y} 1=-0.317+0.476(\mathrm{X} 1)-0.047(\mathrm{X} 2)+0.121(\mathrm{X} 3)+0.222(\mathrm{X} 4)+0.246(\mathrm{X} 5)+0.118(\mathrm{X} 6)+\mathrm{E}$

This model can be used to predict customer retention in the future once the scores of trust, competence, commitment, communication, conflict handling, and bonding are known.

5.6.2 Impact of Relationship Marketing (RM) on Customer Satisfaction

The ANOVA table (table 8 ) indicates a sig. value of 0.000 . The model summary also indicated an R square value of 0.684 . The sig. value of 0.000 indicates that statistically there is a strong significant relationship between relationship marketing and customer satisfaction. The $\mathrm{R}$ square value of 0.684 indicates that 68.40 per cent of variations in customer satisfaction is explained by RM. Therefore, it is concluded that $\boldsymbol{H} \boldsymbol{2}$ is accepted.

This confirms earlier studies by Djajanto, Afiatin, and Haris (2019), Aka, Kehinde, and Ogunnaike (2016), Kyei and Narteh (2016), Narteh (2009), as well as Ndubisi and Wah (2005) which also revealed that variations in customer satisfaction are explained by implementation of effective RM strategies. This implies that improvement in relationship marketing practices by banks will have a positive impact on customer satisfaction.

Table 8: ANOVA (RM and Satisfaction)

\begin{tabular}{lccccc}
\hline & Sum of Squares & df & Mean Square & F & Sig. \\
\hline Regression & 243.334 & 6 & 40.556 & 126.314 & $.000^{\mathrm{a}}$ \\
Residual & 112.374 & 350 & 0.321 & & \\
Total & 355.708 & 356 & & & \\
\hline \hline
\end{tabular}

$$
\mathbf{R}=\mathbf{0 . 8 2 7} \quad \text { R Square }=0.684 \quad \text { Adjusted } \mathrm{R}=\mathbf{0 . 6 7 9}
$$

Table 9 indicates the individual contribution of the various dimensions of RM to customer satisfaction. It shows that trust, competence, commitment, communication, conflict handling and bonding jointly contribute to determine the extent of customer satisfaction. The highest determinant though is trust. This is followed by bonding, communication, commitment, conflict handling and competence respectively. Among these dimensions, trust, bonding, communication, commitment, and conflict handling all have significant effects on customer retention as their $\mathrm{p}$-values are less than $0.05(\mathrm{p}<0.05)$. This is illustrated in table 9 below; 


\begin{tabular}{lccccc}
\hline \multicolumn{7}{c}{ Table 9: Regression (RM and Satisfaction) } \\
\hline & \multicolumn{7}{c}{ Unstandardized Coefficients } & $\begin{array}{c}\text { Standardized } \\
\text { Coefficients }\end{array}$ & t & & Sig. \\
\hline & B & Std. Error & Beta & & 0.000 \\
(Constant) & -0.968 & 0.173 & & -5.587 & 0.000 \\
Trust & 0.519 & 0.058 & 0.377 & 8.953 & 0.107 \\
Competence & -0.098 & 0.060 & -0.073 & -1.617 & 0.002 \\
Commitment & 0.175 & 0.057 & 0.141 & 3.049 & 0.000 \\
Communication & 0.264 & 0.055 & 0.212 & 4.769 & 0.026 \\
Conflict Handling & 0.127 & 0.057 & 0.100 & 2.234 & 0.000 \\
Bonding & 0.296 & 0.052 & 0.235 & 5.658 & \\
\hline \hline
\end{tabular}

The regression (prediction) equation on the above model can be presented as follows:

If Customer Satisfaction $=Y 1$, Trust $=X 1$, Competence $=X 2$, Commitment $=X 3$, Communication=X4, Conflict Handling $=\mathrm{X} 5$, Bonding $=\mathrm{X} 6$ and Error term $=\mathrm{E}$, then

$\mathrm{Y} 1=-0.968+0.519(\mathrm{X} 1)-0.098(\mathrm{X} 2)+0.175(\mathrm{X} 3)+0.264(\mathrm{X} 4)+0.127(\mathrm{X} 5)+0.296(\mathrm{X} 6)+\mathrm{E}$.

This model can be used to predict customer satisfaction in the future once the scores of trust, competence, commitment, communication, conflict handling, and bonding are known.

5.6.3 Impact of Customer Satisfaction on Customer Retention

The ANOVA table (table 10) indicates a sig. value of 0.000 . The model summary also indicates an $\mathrm{R}$ square value of 0.738 . The sig. value of 0.000 (table 10) indicates that statistically there is a strong significant relationship between customer satisfaction and customer retention. The R square value of 0.738 indicates that 73.80 per cent of variations in customer retention is explained by customer satisfaction. Therefore, it is concluded that $\boldsymbol{H} \mathbf{3}$ is accepted.

This confirmed the findings of the study by Darzi and Bhat (2018), Selvarajan and Piratheepan (2013). Alshurideh, Ra'ed, and Alkurdi, (2012) as well as Cohen, Gan, Yong, and Chong, (2007) which revealed that customer satisfaction is an important factor that determines if customers would be retained by a bank. This implies that improvement in strategies to enhance customer satisfaction by banks will have a positive impact on customer retention. However, this finding is contrary to the findings by Chacha (2015) which revealed that a satisfied customer will not always enter into a long-term relationship with a bank. This implies that a satisfied customer will not always be retained by a bank as they might switch to other banks if they have a superior alternative. This underscores the more reason why banks should work towards ensuring the retention of their customers. Hence banks should implement strategies to ensure the retention of their customers since it will have a positive impact on their profitability and survival in the long run.

Table 10: ANOVA (Customer Satisfaction and Retention)

\begin{tabular}{lccccc}
\hline & Sum of Squares & df & Mean Square & F & Sig. \\
\hline Regression & 231.677 & 1 & 231.677 & $1.00 \mathrm{E}+03$ & $.000^{\mathrm{a}}$ \\
Residual & 82.177 & 355 & 0.231 & & \\
Total & 313.854 & 356 & & & \\
\hline \hline
\end{tabular}

Table 11: Regression (Customer Satisfaction and Retention)

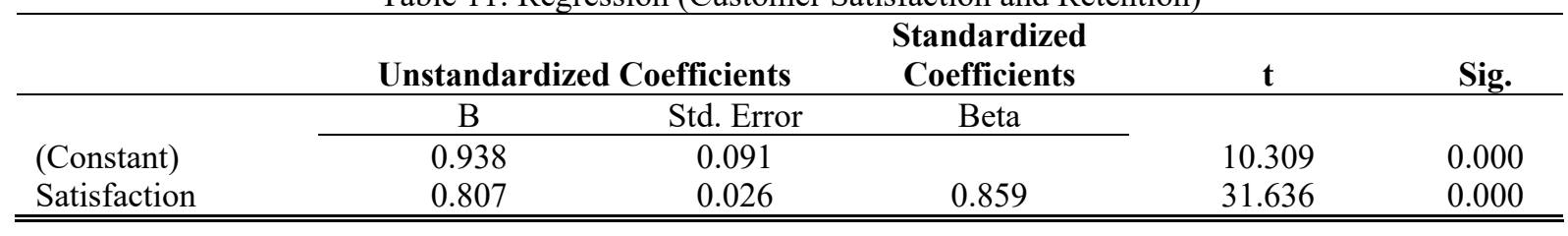

\section{Conclusion and Recommendations for Future Studies}

The study revealed among other things that the implementation of RM practices accounted immensely for the retention of customers in the Ghanaian banking industry. This implies that banks in Ghana which do not effectively implement RM as part of their operations would encounter enormous challenges in retaining their loyal customers. The study also revealed that customer satisfaction also impacts on customer retention. This means that banks that have the objective of retaining their loyal customers need to ensure that they implement customer satisfaction measures, since customer satisfaction results in retention. The study also revealed that banks in Ghana are able to retain their customers even without employing non-financial benefits, which is considered as very essential in the implementation of RM practices. This indicates that banks in Ghana which employ non-financial benefits in addition to financial benefits could have a competitive urge over other competitors in the Ghanaian banking industry. 
There are a number of limitations of this study. One limitation is related to the scope of the study which is limited to the banking industry in Ghana. What this means is that the findings apply to the banking industry and may not be generalized directly to other industries such as the airline and insurance industry. Based on this, it is recommended that future research should include other industries such as the insurance and airline industry so that the findings of these studies can be generalized across other industries. Again a mixed method approach could be adopted for the same study in the future since this study adopted a quantitative approach to the study. Despite these limitations, the study offers practical recommendations on how banks can continue to retain their customers in order to improve their profitability. Therefore, it is expected that banks which implement these recommendations will be able to achieve a competitive urge over their competitors in terms of customer satisfaction and retention of customers and this will lead to enhancement in their profitability and continued survival in the face of stiff challenges in the service industry.

\section{References}

Affum, F. (2020). The Unintended Effects of Bank of Ghana's Clean-Up Exercise on Unaffected Financial Institutions: Evidence from Yilo Krobo Municipality, Ghana. Asian Journal of Economics, Business and Accounting, 1-12.

Aka, D., Kehinde, O., \& Ogunnaike, O. (2016). Relationship marketing and customer satisfaction: A conceptual perspective. Binus Business Review, 7(2), 185-190.

Affum, F. (2020, September 24). Ghanaweb. Retrieved from Ghanaweb: https://www.ghanaweb.com

Aldaihani, F. M. F., \& Ali, N. A. B. (2019). Impact of relationship marketing on customer loyalty of Islamic banks in the state of Kuwait. International Journal of Scientific \& Technology Research, 8(11), 788-802.

Alshurideh, M., Ra'ed, M., \& Alkurdi, B. (2012). The effect of customer satisfaction on customer retention in the Jordanian mobile market: An empirical investigation. European Journal of Economics, Finance and Administrative Sciences, 47, 69-79.

Anabila, P., Narteh, B., \& Tweneboah-Koduah, E. Y. (2012). Relationship marketing practices and customer loyalty: Evidence from the banking industry in Ghana", European Journal of Business and Management, 4, (13), 51-61.

Anderleep, S. (1996). An experimental investigation of satisfaction and commitment in marketing channels:the role of trust and dependance, Journal of Retailing, 72, (1), 77-93.

Anderson, E., \& Weitz, B. (1989). Determinants of continuity in conventional industrial channel dyads, Marketing Science, 8, (4), 18-34.

Anderson, E., \& Weitz, B. (1992). The use of pledges to build and sustain commitment in distribution channels, Journal of Marketing Research, 29, 18-34.

Athanassopoulos, A. (2000). Customer satisfaction cues to support market segmentation and explain switching behaviour, Journal of Business Research, 47 (3), 191-207.

Berry, L. (1983). Relationship marketing, in Berry, L.L., Shostack, G.L. and Upah, G.D. (Eds),. Emerging Perspectives of Services Marketing, American Marketing Association, Chicago, IL.

Calaghan, M., McPhail, J., \& Yau, O. (1995). Dimensions of relationship marketing orientation:an empirical exposition, Proceedings of the 7th Bianual World Marketing Congress July, 10-65). Melbourne, Australia.

Chacha, M. (2015). Customer relationship marketing and its influence on customer retention: a case of commercial banking industry in Tanzania. Proceedings of the Third Middle East Conference on Global Business, Economics, Finance and Banking.

Christopher, M., Payne, A., \& Ballantyne, D. (1991). Relationship marketing bringing quality, customer service and marketing together. Oxford: Butterworth-Heinemann.

Cohen, D., Gan, C., Yong, H. H., \& Chong, E. (2007). Customer retention by banks in New Zealand, Banks and Bank Systems, 2 (1), 40-55.

Copulsky, R., \& Wolf, J. (1990). Relationship marketing: positioning for the future, The Journal of Business strategy, July- August, 16-20.

Cronbach, L. J. (1951). Coefficient alpha and the internal structure of the tests, Psychometrika, 16, $297-334$.

Crosby, L., Evans, K., \& Cowless, D. (1990). Relationship quality in services selling: an interpersonal influence perspective, Journal of Marketing, 54 (3), 68-81.

Darzi, M. A., \& Bhat, S. A. (2018). Personnel capability and customer satisfaction as predictors of customer retention in the banking sector. International Journal of Bank Marketing.

Dawkins, P., \& Reichheld, F. (1990). Customer retention as a competitive weapon. Directors and Board, 14, Summer, 42-47.

Djajanto, L., Afiatin, Y., \& Haris, Z. A. (2019). The impact of relationship marketing on customer value, satisfaction and loyalty: evidence from banking sector Indonesia. International Journal of Economic Policy in Emerging Economies, 12(2), 207-214.

Dwyer, F., Schurr, P., \& Oh, S. (1987). Developing buyer-seller relationships, Journal of marketing, 71, 11-27. 
Ericksson, K., \& Lofmarck, V. A. (2000). Customer retention, purchasing behaviour and relationship substance in professional services. Industrial Marketing Management, 29 (4), 363-372.

Filip, A., \& Anghel, L.-D. (2006). The applicability of relationship marketing approach in the financial services industry. Main benefits of customer retention for banking organizations, Conference on Marketing and Development 1971-2006: Romania. Bucureşti, ASE, pp. 944-947.

Gan, L., Sim, C.J., Tan, H.L. \& Tna, J. (2007). Online relationship marketing by Singapore hotel websites, Journal of Travel and Tourism Marketing, 20 (3/4), 1-19.

Gerpott, T., Rams, W., \& Schindler, A. (2001). Customer retention, loyalty, and satisfaction in the German mobile cellular telecommunications market, Telecommunications Policy, 249-269.

Grönroos, C. (1991). The marketing strategy continuum: A marketing concept for the 1990's", Management Decision, 29 (1), 7-13.

Gronroos, C. (1994). From marketing mix to relationship marketing:Towards a paradigm shift in marketing, Management Decision, 32 (2), 4-20.

Grönroos, C. (1995). Relationship marketing: The strategy continuum, Journal of the Academy of Marketing Science, 23 (4), 252-254.

Gronroos, C. (2001). The perceived service quality concept - a mistake?, Managing Service Quality, 11(3) , 1502.

Grossman, R. (1998). Developing and managing effective consumer relationships", Journal of Product \& Brand Management, 7 (1), 27-40.

Hair, J. F., Black, W. C., Babin, B. J., Anderson, R. E., \& Tathan, R. L. (2006). Multivariate Data Analysis, Sixth Edition. New Jersey: Pearson.

Hair, J. J., Anderson, R., Tatham, R., \& Black, W. (1998). Multivariate Data Analysis. Englewood Cliffs,NJ.: Prentice-Hall Inc.Relationship Marketing 555.

Hettiarachchy, B. S., \& Samarasinghe, D. S. R. (2016, December). Influence of Relationship Marketing on Customer Retention in Sri Lankan Banking Industry. In University of Sri Jayewardenepura, Sri Lanka, 13th International Conference on Business Management (ICBM).

Hinde, R. (1997). Relationship: A Dialectical Perspective,. Hove: Psychology Press.

Husnain, M., \& Akhtar, W. (2016). Relationship marketing and customer loyalty: Evidence from banking sector in Pakistan. Global Journal of Management and Business Research 15 (10).

Kotler, P., \& Keller, K. (2006). Marketing Management, 12th edition. New Jersey: Pearson,Prentice Hall.

Kyei, D. A., \& Narteh, D. B. (2016). Relationship Marketing Practices and Customer Satisfaction in the Ghanaian banking Sector. European Journal of Business and Management, 8(16).

Lee, G., \& Lin, H. (2005). Customer perceptions of e-service quality in online shopping, International Journal of Retail \& Distribution Management, 33 (2), 161-176.

Lindgreen, A., Davis, R., Brodie, R., \& Buchanan-Oliver, M. (2000). Pluralism in contemporary marketing practices", International Journal of Bank Marketing, 18 (6), 294-308.

Martin, M., \& Sohi, R. (1993). Maintaining relationships with customers: some critical factors. AMA Educators' Proceedings: Enhancing Knowledge Development in Marketing, 21-7. Chicago.

Meunier-FitzHugh, K., \& Piercy, N. (2010). Improving the relationship between sales and marketing, European Business Review, 287-305.

BIBLIOGRAPHY \1 1033 Modern Ghana. (2020, 09 28). Retrieved from modern Ghana Web Site: https://www.modernghana.com

Moorman, C., Zaltman, G., \& Deshpande, R. (1992). Relationships between providers and users of market research: the dynamics of trust within and between organizations, Journal of Marketing Research, 29 (3), 314-28.

Morgan, R., \& Hunt, S. (1994). The Commitment-Trust Theory of Relationship Marketing, Journal of Marketing , 20-38.

Mowday, R., Porter, L., \& Steers, R. (1982). Organizational linkages: the psychology of commitment", Journal of Vocational Behavior, 14 (4), 224-47.

Msoka, Caroline, M., \& Msoka, Elizabeth, M. (2014). Determinants of Customer Retention in Commercial Banks in Tanzania. Journal of Finance and Bank Management, 2 (1), 9-30 ISSN: 2333-6064 (Print), 2333-6072 (Online).

Mukherjee, A. \& Nath, P. (2007). Role of electronic trust in online retailing: a re-examination of the commitmenttrust theory, European Journal of Marketing, 41 (9/10), 1173-1202.

Narteh, B. (2009). Relationship marketing and customer satisfaction in the Ghanaian banking sector, Journal of Retail Marketing Management Research (JRMMR), 2 (1), 15-19.

Ndubisi, N. (2004). Understanding the salience of cultural dimensions on relationship marketing, its underpinnings and aftermaths. New York: Cross cultural management,11(3).

Ndubisi, N. (2006). Effect of gender on customer loyalty: a relationship marketing approach, Marketing 
Intelligence \& Planning, 48-61.

Ndubisi, N. (2007). Relationship marketing and customer loyalty, Marketing intelligence and planning, 25 (1), 98-106.

Ndubisi, N., \& Wah, C. K. (2005). Factorial and discriminant analyses of the underpinnings of relationship marketing and customer satisfaction. International Journal of bank Marketing, 542-557.

Nunnally, J. C. (1978). Psychometric theory. New York: McGraw-Hill Inc.

Nusair, K.K., Bilgihan, A., \& Okumus, F. (2013). The role of online social network travel websites in creating social interaction for gen Y travelers, International Journal of Tourism Research, 15 (5), 458-472.

Oliver, R. (1999). Whence customer loyalty?, Journal of Marketing, 63, 33-44.

Olotu, A. O., Maclayton, D. W., \& Opara, B. C. (2010). An Empirical Study of Relationship Marketing Orientation and Bank Performance, Research Journal of Internatıonal Studies - Issue 16. , 47-57.

Prahalathan, M. B., Umakanth, M. N., \& Dineshkumar, M. S. (2016). Relationship Marketing and Customer Retention: An Empirical Investigation in Banking Sector, Sri Lankan Context. International Journal of Research in IT \& Management,6(6). 6-15.

Reichheld, F., \& Sasser, W. (1990). Zero defections:quality comes to service, Harvard Business Review, 68 (9), $105-111$.

Rindova, V., \& Fombrum, C. (1999). Constructing competitive advantage: the role of firm constituent interactions, Strategic Management Journal, 20, 691-710.

Rootman, C., Tait, M., \& Sharp, G. (2011). Relationship marketing and customer retention lessons for South African banks, Southern African Business Review, 15 (3), 184-206.

Selvarajan, P., \& Piratheepan, U. (2013). Customer Satisfaction Towards Customer Retention in the Private Banking Sector: A Study on Selected Private Sector Banks in Vavuniya District of Sri Lanka. South Asian Journal of Marketing \& Management Research, 3(10), 45-55.

Sherma, A., Krishnan, R., \& Grewal, D. (2001). Value creation in markets, Industrial Marketing Management, 30, 391-402.

Sheth, J., \& Parvatiyar, A. (2000). The evolution of relationship marketing, in Sheth, J.N. and Parvatiyar, A. (Eds), Handbook of Relationship Marketing. London: Sage.

Sin, L. Y., Tse, A. C., Yau, O. H., Lee, J. S., \& Chow, R. (2002). The effect of relationship marketing orientation on business performance in a service-oriented economy. Journal of Services Marketing, 16 (7), 656-676.

Smith, B. (1998). Buyer-seller relationship:Bonds,relationship management, and sex type, Canadian Journal of Administrative Sciences, 15 (1), 76-92.

Taleghani, M., Gilaninia, S., \& Mousavian, S. J. (2011). The Role of Relationship Marketing in Customer Orientation Process in the Banking Industry with focus on Loyalty (Case Study: Banking Industry of Iran)" International Journal of Business and Social Science, 155-166.

Verhoef, P. C. (2003). Understanding the Effect of Customer Relationship Management Efforts on Customer Retention and Customer Share Development, Journal of Marketing, 67, 30-45.

Wah, C. K. (2004). Examining the antecedents of relationship quality, customer satisfaction and customer loyalty. Unpublished MBA thesis, University of Malaysia Sabah, Kota Kinabalu.

Wah, C,, K., \& Ndubisi, N. O. (2004, October). Building customer loyalty in the digital age through relationship marketing (RM) and the mediation effect of trust. In Proceedings of the 5th International Conference on Operations and Quantitative Management, Seoul, South Korea, Korea (293-302).

Walsh, S., Gilmore, A., \& Carson, D. (2004). Managing and implementing simultaneous transaction and relationship marketing. International Journal of Bank Marketing, 22 (7), 468-83.

Zineldin, M. (2000). TRM, Total Relationship Management. Lund: Studentlitteratur. 